\title{
BRIDGING THE INTERNATIONAL GAP: THE ROLE OF NATIONAL HUMAN RIGHTS INSTITUTIONS IN THE IMPLEMENTATION OF HUMAN RIGHTS TREATIES IN AFRICA
}

\author{
Aliyu Ibrahim* \\ LLB LLM \\ Doctoral Student \\ School of Law, University of KwaZulu-Natal
}

\section{SUMMARY}

While most of the United Nations (UN) treaties have committees to monitor the implementation of their provisions among their States parties, one of the major challenges they encounter is their inability to independently verify the information provided by the States parties, on the level of fulfilling their obligations to the treaties. However, the establishment of National Human Rights Institutions (NHRIs) by the majority of UN member states was meant to not only promote and protect human rights within the territories of States parties, but also to monitor the implementation of the provisions of treaties at the domestic level. This resulted in treaty bodies to encourage NHRIs, in monitoring and providing it with information on the level of implementation of the provisions of these treaties within the territories of respective States parties. This article examines whether these institutions in Africa have been able to discharge their mandates concerning the implementation of two treaties, namely, the International Covenant on Civil and Political Rights (ICCPR) which is monitored by the Human Rights Committee (HRC) and the International Covenant on Economic, Social and Cultural Rights (ICESCR) which is overseen by the Committee on Economic, Social and Cultural Rights (CESCR). The NHRIs of South Africa, Morocco and Nigeria have been selected to test the effectiveness of these institutions. The study ultimately shows that the majority of these institutions are still far off from achieving their potential.

\section{INTRODUCTION}

International law at its inception, regulated the relationships between states only. The affairs of citizens of each state were left to be attended to by each individual state with the rights of aliens (foreigners) and in some instances, humanitarian interventions provided for by some states. ${ }^{1}$ The horrific

* The author would like to express his gratitude to Professor Nomthandazo Ntlama and Mrs Clydenia Stevens for their support and guidance in the production of this article. All errors and omissions remain the author's.

1 McGoldrick The Human Rights Committee: It's Role in the Development of the International Covenant on Civil and Political Rights (1994) 3. 
violations of human rights that occurred during the Second World War made the international community see the urgent need to protect individuals and vulnerable groups against the violations of their human rights by states. ${ }^{2}$ This concern led to the establishment of the United Nations in 1945, with one of its key objectives bearing on the need to promote and protect human rights among member states. ${ }^{3}$ The first human rights instrument to be proclaimed by the UN was the Universal Declaration of Human Rights (UDHR) 1948. ${ }^{4}$ The UDHR was the first instrument that made up the International Bill of Human Rights. The two others that were adopted by the UN on 16 December 1966 were the International Covenant on Civil and Political Rights, ${ }^{5}$ and the International Covenant on Economic, Social and Cultural Rights. ${ }^{6}$ These two Covenants, unlike the UDHR, are legally binding treaties for those states that are parties to them.

As such, the ICCPR, ${ }^{8}$ is a treaty that incorporates the civil and political rights aspect contained in the UDHR. ${ }^{9}$ It consists of 27 provisions that guarantee diverse human rights, which are the broadest among all the treaties established at the UN level. ${ }^{10}$ These rights include gender equality, ${ }^{11}$ right to life ${ }^{12}$ prohibition of torture, ${ }^{13}$ and right to security and liberty of person, ${ }^{14}$ to mention a few. To supervise the implementation of the provisions of the ICCPR, a body was created by the treaty known as the Human Rights Committee ${ }^{15}$ which examines reports submitted by the state regarding the implementation of the ICCPR within their territories. ${ }^{16}$ It also receives complaints, where persons allege that any of their rights contained in the ICCPR have been violated by any States party to the First Optional Protocol. An individual can submit "communications" (complaints) to the HRC against that States party. ${ }^{17}$ It also issues general comments, which are commentaries on the scope of rights contained in the ICCPR. ${ }^{18}$ The HRC is

2 Ladan Materials and Cases on Public International Law (2007) 169.

3 Article 1(3) of the Charter of the United Nations and Statute of the International Court of Justice, adopted in San Francisco on the 6th June 1945, after the conclusion of the United Nations Conference on International Organisations and came into force on the 24 October 1945.

General Assembly Resolution 217A, in Paris on 10 December 1948.

General Assembly Resolution 2200A (XXI).

Ibid.

Ladan Materials and Cases on Public International Law 173.

Adopted by UN General Assembly Resolution 2200A (XXI) on 16 December 1966, entered in to force on the 23rd March 1976.

9 Simmons "Civil Rights in International Law: Compliance with Aspects of the 'International Bill of Rights"” 2009 16(2) Indiana Journal of Global Legal Studies 437440.

10 Buergenthal "The U.N. Human Rights Committee" 2001 Max Planck Yearbook of United Nations Law 341342

Article 2 ICCPR.

Article 6 ICCPR.

Article 7 ICCPR.

Article 9 ICCPR.

Article 28 ICCPR.

Article 40(1) ICCPR.

Adopted by the UN General Assembly Resolution 2200A (XXI) on 16 December 1966, entered in to force on the $23^{\text {rd }}$ March 1976, article 1.

18 Article 40(4) ICCPR. 
described as the "most active and innovative" of all treaty bodies because of the measures it has been taking to ensure the implementation of the treaty. ${ }^{19}$

The ICESCR equally incorporates the Economic, Social and Cultural (ESC) rights component of the UDHR, ${ }^{20}$ some of which include: right to work, ${ }^{21}$ right to education, ${ }^{22}$ and cultural rights. ${ }^{23}$ The treaty did not establish a monitoring mechanism for the implementation of the provisions of the treaty, but left the responsibility to the Economic and Social Council (ECOSOC) and other specialised bodies. ${ }^{24}$ However, in 1985, a supervising committee known as the Committee on Economic, Social and Cultural Rights (CESCR), was established by ECOSOC. They also operate like the HRC by reviewing state reports and issuing general comments. ${ }^{25}$ The Optional Protocol to the ICESCR came into force on 5 May 2013, which allows it to receive complaints from individuals within the territories of States parties to the Protocol on breaches of the provisions of the ICESCR. ${ }^{2}$

Despite the above external mechanisms, Bayefsky asserts that the lack of supervisory mechanisms within the territories of states results in their making unverifiable claims of fulfilment of obligations to the various treaties they are parties to. ${ }^{27}$ The UN, in its efforts to ensure the promotion and protection of human rights by its member states, has been calling on the states to establish National Human Rights Institutions which are referred to as "an answer to the old question of the implementation" of treaty obligations within the domestic territories of states. ${ }^{28}$

\section{ESTABLISHMENT OF NHRIs}

$\mathrm{NHRI}$ is defined by the UN as a "Government body established under the constitution or by law, whose functions are specifically designed to promote and protect human rights". Due to the importance of these institutions, the Office of the High Commissioner for Human Rights (OHCHR) continues to financially support the creation of NHRIs in member states of the UN, which results in the institutions being considered as "less national institutions and more an international project". 29

\footnotetext{
Buergenthal 2001 Max Planck Yearbook of United Nations Law 342.

Rehman International Human Rights Law 2ed (2010) 85.

Article 6 ICESCR.

Article 13 ICESCR.

Article 15 ICESCR

Article 16(1) ICESCR

Dennis and Steward "Justiciability of Economic, Social and Cultural Rights: Should there be an International Complaint Mechanism to Adjudicate the Rights to Food, Water, Housing and Health?" 200498 American Journal of International Law 462462.

26 Committee on Economic, Social and Cultural Rights "Monitoring the Economic, Social and Cultural Rights" www.ohchr.org/EN/HRBodies/CESCR/Pages/CESCRIntro.aspx (accessed 2018-06-17).

27 Bayefsky "Making Human Rights Treaties Work" 199426 Transnational Legal Policy 229 233.

28 Carver "A New Answer to an Old Question: National Human Rights Institutions and the Domestication of International Law" 2010 10(1) Human Rights Law Review 130.

29 Carver 2010 10(1) Human Rights Law Review 2.
} 
There is no uniform nomenclature of naming NHRIs, but they rather have different names depending on the state and legal tradition. For example, Human Rights Commission, Ombudsman and Public Defender or Protector, are some of the common names given to NHRIs. ${ }^{30}$ However, the majority are referred to as Ombudsmen or Human Rights Commissions, and there are those NHRIs that are specialised national institutions that cater for identified vulnerable groups like children, refugees and minority rights. ${ }^{31}$ Due to the interest of the UN in encouraging its member states to create NHRIs, there has been an increasing number of their establishment by States parties around the world; however, it was observed that there was an apparent reluctance by the states to be held accountable by their own creations. As for some states, the purpose of establishing some of these institutions was just a smokescreen to divert the attention of the international community from their appalling human rights records. ${ }^{32}$ To guard against creating dummy NHRIs, the UN, adopted a resolution, ${ }^{33}$ which created the Principles relating to the Status of National Institutions (Paris Principles) calling on member states to establish NHRls vested with the competence to promote and protect human rights. ${ }^{34}$ It further provided that states must vest on the NHRIs as broad a mandate as possible, to be able to discharge their duties effectively. ${ }^{35} \mathrm{~A}$ minimum benchmark was set by the Paris Principles for NHRIs to be able to operate effectively in bridging the gap between international human rights law and domestic law which include:

- To synchronise domestic legislation with international treaties which the state is a party to and their subsequent implementation, ${ }^{36}$

- Promote the ratification or accession of treaties and their implementation; ${ }^{37}$

- Assist in preparation of state reports to be submitted to a UN organ or committee, express an independent view where it is required without compromising their independence, ${ }^{38}$ and

- Collaborate with the UN, Regional institutions and other state national institutions for the protection of human rights.

NHRIs that fulfil the requirements of the Paris Principles, are accredited with an "A" status by the recognised accreditation body known as Global Alliance of National Human Rights Institutions (GANHRI). ${ }^{40}$ There are currently 120 recognised NHRIs globally, with 77 having an "A" status, which

30 "Introducing National Human Rights Institutions" 20101 Human Rights Institutions History Roles and Responsibilities 13-14.

31 Human Rights Watch Protectors or Pretenders? Government Human Rights Commissions in Africa (2001) 10.

32 Brodie "Uncomfortable Truths: Protecting the Independence of International Human Rights Institutions to Inquire" 201538 University of New South Wales Law Journal 12151217.

Adopted by the General Assembly Resolution 48/134 on 20 December 1993.

34 Article 1 of the Paris Principles.

Article 2 of the Paris Principles.

Article $3(b)$ of the Paris Principles.

Article 3(c) of the Paris Principles.

Article 3(d) of the Paris Principles.

Article 3(e) of the Paris Principles.

40 "A brief history of ICC" http://nhri.ohchr.org/EN/AboutUs/Pages/History.aspx (accessed 2016-10-24). 
means they have complied with all the requirements specified in the Paris Principles, with Africa having $20 .^{41}$ In addition to this, the UN General Assembly adopted a resolution, which calls on all UN mechanisms to encourage accredited NHRIs to participate in their activities that involve the promotion and protection of human rights. ${ }^{42}$

In recognition of the potential benefits to its monitoring functions, the HRC encourages NHRIs to partner with it in overseeing the implementation of the provisions of the ICCPR, by individual states. ${ }^{43}$ The CESCR also enjoined States parties to confer NHRIs the mandate to protect the provisions of the ICESCR within their territories. ${ }^{44}$ It is on this background that this article will examine the effectiveness of NHRIs within particular African States parties, concerning their contributions to the fulfilment of the mandate of the HRC. Consequently, attention is given to the South African Human Rights Commission (SAHRC), National Human Right Council of Morocco (CNDH) and the Nigerian National Human Rights Commission (NHRC). They are examined in more detail in the course of this article, as they are among those that have been accredited with an "A" status by GANHRI. ${ }^{45}$ The study of these three examples gives an insight into how NHRIs operate in Africa, and it will also reveal whether the promise of NHRls to be a better pathway into the implementation of international human rights has been realised as prescribed by the Paris Principles. ${ }^{46}$

41 "Chart of the Status of National Institutions: Accredited by the Global Alliance of National Human Rights Institutions" accreditation status as of 26 May, 2017; "Chart of the Status of National Institutions: Accredited by the Global Alliance of National Human Rights Institutions" accreditation status as of 21 February $2018 \mathrm{https}: / /$ nhri.ohchr.org/EN/AboutUs/ GANHRIAccreditation/Documents/Status\%20Accreditation\%20Chart.pdf (accessed 201806-22); African NHRIs that have an "A" status accreditation are: Cameroon, Egypt, Ghana, Kenya, Liberia, Malawi, Mauritania, Mauritius, Morocco, Namibia, Niger, Nigeria, Rwanda, Sierra Leone, South Africa, Tanzania, Togo, Uganda, Zambia, Zimbabwe.

42 UN General Assembly Resolution No: A/Res170/163, adopted on the 17 December 2015.

43 "Paper on the Working Relationship between Human Rights Committee with National Human Rights Institutions" adopted by the Committee at its $106^{\text {th }}$ Session $(15$ October-2 November 2012) UN Doc No: CCPR/C/106/3 par 4 http://tbinternet.ohchr.org/_layouts/ treatybodyexternal/Download.aspx?symbolno=CCPR\%2fC\%2f106\%2f3\&Lang=en (accessed 2015-08-15)

44 Committee on Economic, Social and Cultural Rights: General Comment No: 10 on the role of National Human Rights Institutions in the protection of Economic, Social and Cultural Rights adopted at the $51^{\text {st }}$ meeting (nineteenth session) on 1 December 1998 UN DOC NO: E/C.12/1998/25 par 4.

45 Chart of the status of National Institutions.

46 Durojaiye "Turning Paper Promises to Reality: National Human Rights Institutions and Adolescent's Sexual and Reproductive Rights in Africa" 2008 24(4) Netherlands Quarterly of Human Rights 547578. 


\section{SOUTH AFRICA: HUMAN RIGHTS COMMISSION (SAHRC)}

\section{Scope of mandate}

In South Africa, international law cannot become law without having being approved by the National Assembly and the National Council of Provinces. ${ }^{4}$ However, where a treaty has a self-executing clause and is approved by Parliament it becomes law as long as it is not in conflict with the Constitution or any law in force. ${ }^{48}$ South African courts are also enjoined to interpret the law in line with international law. ${ }^{49}$ The South African Human Rights Commission (SAHRC) was established and given a broad mandate for the promotion and protection of human rights generally, ${ }^{50}$ with the additional responsibility to oversee the implementation of socio-economic rights as part of its mandate. ${ }^{51}$ The SAHRC is a creation of the Constitution of the Republic of South Africa, ${ }^{52}$ as one of the chapter 9 institutions established to support constitutional democracy. ${ }^{53}$ Bearing in mind that the South African Constitution (supreme law of the land) provides the SAHRC with a comfortable foundation from which to operate, its independence is guaranteed, and shall be subject to the South African Constitution and other South African Laws. ${ }^{54}$ State organs are also mandated to protect its independence ${ }^{55}$ as interference with its functions is prohibited by the Constitution, ${ }^{56}$ and also, the SAHRC renders account of its activities to the Parliament at least once a year. ${ }^{57}$

Evidence of its broad mandate is encapsulated in the Constitution which further provides for other functions of the SAHRC with regards to the promotion of human rights. These include for example its mandate to promote, respect and protect human rights generally, ${ }^{58}$ where it shall monitor the implementation of human rights within the territory of the state. ${ }^{59}$ It is also responsible for the investigation and making available its findings on the

\footnotetext{
S 231(2) of the Constitution of the Republic of South Africa 1996.

S 231(4) of the Constitution of the Republic of South Africa.

S 233 Constitution of the Republic of South Africa.

Stevens and Ntlama "An Overview of South Africa's Institutional Framework in Promoting Women's Right to Development" 201620 Law Democracy and Development 4661.

51 Mubangizi "A Comparative Discussion of the South African and Ugandan Human Rights Commissions" 2015 48(1) Comparative and International Law Journal of Southern Africa 124128.

52 See South African Human Rights Commission Act 40 of 2013 which provides the composition, powers and functions of the Commission.

53 S 181(1) of the Constitution of the Republic of South Africa; other institutions are: The Public Protector, The Commission for the Promotion and Protection of the Rights of Cultural, Religious and Linguistic Communities, The Commission for Gender Equality, The Auditor-General, The Electoral Commission.

$54 \mathrm{~S}$ 181(2) of the Constitution of the Republic of South Africa.

55 181(3) of the Constitution of the Republic of South Africa.

56 S 181(4) of the Constitution of the Republic of South Africa.

5 S 181(5) of the Constitution of the Republic of South Africa.

58 S 184(1)(a)-(b) of the Constitution of the Republic of South Africa.

59 S 184(1)(c) of the Constitution of the Republic of South Africa.
} 
level of compliance with human rights generally, ${ }^{60}$ and in cases of human rights violations, the SAHRC shall seek appropriate remedies for those violations. ${ }^{61}$ It equally undertakes appropriate research and also, organises public enlightenment on human rights issues within the territory of the State. $^{62}$

In keeping with it's accredited "A" status, ${ }^{63}$ the SAHRC is mandated to embark on public awareness in its role of promotion and protection of human rights as contained in the Bill of Rights and other legislation, ${ }^{64}$ and also conduct research and educate the public on human rights. ${ }^{65}$ Further, at the international level, the SAHRC monitor the implementation of both international and regional human rights treaties within the jurisdiction of the States party. ${ }^{66}$ It also advises the States party and its organs on steps to take in the protection of human rights in accordance with the Constitution and the laws in force. ${ }^{67}$

\section{Reporting obligations before charter bodies}

\section{Submission of reports before the Human Rights Committee}

The HRC encourages the submission of alternative reports by NHRls of States parties. ${ }^{68}$ Interestingly, the SAHRC has been identified as one of the NHRIs in Africa that has been consistent in preparing and submitting alternative reports to UN treaty bodies. ${ }^{69}$ South Africa submitted its initial report to the HRC for review in $2014 .^{70}$ The SAHRC as requested by the HRC, equally submitted a comprehensive alternative report to the HRC making recommendations to be included in the List of Issues (LOIs) that the HRC forwarded to the States party for its response. ${ }^{71}$ The SAHRC report raised some vital issues, which needed to be addressed by the States party. It pointed out that it received 9217 complaints from the public in 2014, prior to its submission of the report. However, lack of adequate funding by the State inhibited its ability to discharge its mandate effectively, and urged the

S 184(2)(a) of the Constitution of the Republic of South Africa.

$\mathrm{S}$ 184(2)(b) of the Constitution of the Republic of South Africa.

S 184(2)(c)-(d) of the Constitution of the Republic of South Africa.

Chart on the status of National Institutions par 4.

S 13(1)(a)(ii) of the South African Human Rights Commission Act 40 of 2013.

Ibid.

S 13(1)(a)(vi) of the South African Human Rights Commission Act.

S 13(1)(a)(i) of the South African Human Rights Commission Act.

68 Paper on the working relationship between the HRC and NHRls http://tbinternet.ohchr.org/_layouts/treatybodyexternal/Download.aspx?symbolno=CCPR\%2 fC\%2f106\%2f3\&Lang=en par 14 .

69 Durojaiye 2008 24(4) Netherlands Quarterly of Human Rights 577.

70 Consideration of reports submitted by States parties under Article 40 of the Covenant: Initial Report of South Africa 7 March 2016 UN DOC CCPR/C/SR.3234 par 9.

71 South African Human Rights Commission: List of issues to the Human Rights Committee on South African implementation of the International Covenant on Civil and Political Rights 17 April 2015. 
HRC to inquire from the States party in the LOls the steps it had taken in strengthening the SAHRC to be able to discharge its mandate fully. ${ }^{72}$

Regarding the implementation of the provisions of the ICCPR by the States party, the SAHRC observed that the right to life, which is an absolute right, guaranteed in the South African Constitution, ${ }^{73}$ and is consistent with article 6 of the ICCPR is violated, as there continued to be a high incidence of individual deaths at the hands of law enforcement officers, which continue to increase annually. To stem the tide of loss of lives, an Independent Police Investigative Directorate (IPID) was established to investigate complaints against police misconduct, but there has not been any significant change, in the complaints of extra-judicial killings by the police despite the coming into being of IPID. ${ }^{74}$ Also, there continues to be a series of violent public protests, which equally lead to loss of lives in some cases, when the police tried to contain these protests, for instance, 34 mineworkers at Marikana, North West Province of South Africa, were killed by the police in its bid to control protests by the striking mine workers. ${ }^{7}$ Furthermore, it was also recommended that the States party furnish to the HRC information on steps it will take to promote peaceful protests among its communities, and also, information on the interim findings of the Marikana Commission of Inquiry relating to the lawfulness of the killings of miners. ${ }^{76}$

The right to liberty and security of person is protected by section 12 of the South African Constitution, which is in cognisance with article 9 of the ICCPR. However, the SAHRC report pointed out that the Government is facing challenges, in protecting the right of security of persons, most especially with regards to vulnerable groups and foreign nationals. Among vulnerable groups in South Africa, lesbians, gays, bisexuals and transgender (LGBTIs) were identified as the most affected, while foreign nationals also experienced xenophobic attacks in 2008, with 62 persons losing their lives. As a result of these violations, the HRC was asked to request information on the steps taken to increase the presence of South African Police Service (SAPS) in townships and settlements to protect members of the vulnerable groups and foreign nationals from unlawful violations of their rights. ${ }^{77}$

With regards to detained foreign nationals scheduled for deportation to their home countries, the SAHRC had conducted an investigation on their treatment at the Lindela Repatriation Centre, and found that such persons are held in custody for periods of time longer than the 120 days maximum limit prescribed by law, and the authorities failed to inform them of their rights. ${ }^{78}$ Consequent upon these findings by the SAHRC, it sought the HRC to inquire from the States party what machinery it had put in place to

South African Human Rights Commission list of issues 15.

$\mathrm{S} 11$ of the Constitution of the Republic of South Africa.

South African Human Rights Commission list of issues 16.

"Marikana Massacre 16 August 2012" http://www.sahistory.org.za/article/marikanamassacre-16-august-2012 (accessed 2017-10-12).

76 South African Human Rights Commission list of issues 18.

77 South African Human Rights Commission list of issues 24.

78 Summary of record of the $3235^{\text {th }}$ meeting of the HRC where it considered the initial periodic report of South Africa submitted under article 40 ICCPR on 8 March 2016 UN DOC NO: CCPR/C/SR.3235 par 57. 
improve the conditions of its detention centres, not only limited to overcrowding. What action has the Government taken to address the human rights violations uncovered in the investigations conducted by SAHRC in Lindela Repatriation Centre and Groenpunt Maximum Security Correctional Centre and has the Government introduced more programmes that aim to rehabilitate those in custody, so that when they are released, they will be successfully integrated into society?

Thus, when the HRC adopted and forwarded its LOls to South Africa, ${ }^{80}$ it included some of the contributions of SAHRC, which included a request for information on efforts by the States party to control the occurrence of xenophobia, findings on investigations of such cases that occurred and whether persons involved in the attacks, including security officials were prosecuted. $^{81}$ It also requested information from the States party on measures taken in safeguarding the human rights of LGBTIs, and whether they were effective. ${ }^{82}$ Information of excessive use of force by SAPS in police cells and in the exercise of their other functions was equally requested by the HRC. It further sought information on the number of complaints lodged against members of SAPS for the preceding five years on acts of violence against individuals, investigations conducted on these complaints, and disciplinary actions taken on those found culpable of the act of violence complained of. The HRC also, in the LOls inquired to know the level of support given to the IPID in safeguarding its independence to conduct investigations into human rights violations of individuals by members of SAPS. ${ }^{83}$ The HRC requested updated information on the Marikana incident, outlining the role of SAPS in the incident and if any person had been prosecuted for the deaths of the miners, and when the States party intended to publish the findings of its investigations into the Marikana incident. ${ }^{84}$ Finally, information on measures taken by the States party to improve the standards of its detention centres generally and reduce the overcrowding affecting most of them was sought by the HRC. ${ }^{85}$

During the review of South Africa's initial report by the HRC, the SAHRC was commended for its effectiveness and independence in carrying out its mandate. ${ }^{86}$ The HRC followed up on the submissions of the SAHRC to it and raised some concerns in the implementation of the ICCPR by the States party to the South African delegation present, as it sought to know how acts of xenophobia and racism were monitored among law enforcement officers and whether the recommendations made by SAHRC on SARS had been implemented. ${ }^{87}$ Additionally, information on measures the States party has adopted in training health workers and law enforcement officers in catering

79 South African Human Rights Commission list of issues 26.

80 List of Issues in relation to the initial report of South Africa 19 August 2015 UN DOC NO: $\mathrm{CCPR} / \mathrm{C} / \mathrm{ZAF} / \mathrm{Q} / 1$.

81 List of issues in relation to South Africa par 2.

82 List of issues in relation to South Africa par 8.

83 List of issues in relation to South Africa par 11.

84 List of issues in relation to South Africa par 12.

85 List of issues in relation to South Africa par 21.

86 Consideration of reports submitted by States parties under Article 40 of the Covenant: Initial report of South Africa 7 March 2016 UN DOC NO: CCPR/C/SR.3234.

87 Consideration of report submitted by South Africa par 11 . 
for the needs of LGBTIs was requested by the HRC. ${ }^{88}$ Explanations on the loss of lives of 44 miners at Marikana were sought, together with the steps taken by the States party to investigate, prosecute and punish those found guilty.

With regards to the submission of communications under the first optional protocol (OP1) to the ICCPR which South Africa is a party to, ${ }^{90}$ the SAHRC has not had the opportunity to assist individuals that seek to submit communications to the HRC under OP1. During the review of the States party report, it was observed that only two communications had been submitted to the HRC for its determination thus far. The HRC called on the States party to create more awareness among its populace on the availability of the individual complaint mechanism under OP1. ${ }^{91}$ The SAHRC is equally expected to monitor and submit a report to the HRC on the level of implementation of recommendations made by the HRC to the States party as requiring immediate implementation within a year of issuing concluding observations concerning South Africa. ${ }^{92}$ The SAHRC has however failed to do so, as it is the States party that has so far submitted a report outlining the level of its compliance with the concluding observations of the HRC. ${ }^{93}$

\section{SAHRC report to the Committee on Economic, Social and Cultural Rights}

Among the NHRIs in Africa, the SAHRC has the most comprehensive mandate on the implementation of economic and cultural rights (ECR). ${ }^{94}$ The South African Constitution mandates the NHRI to collate on an annual basis, information from the relevant Government organs on the measures taken in the realisation of ESC rights contained in the Bill of Rights, most especially those relating to the provision of housing, healthcare, food, water, social security, education and the environment. ${ }^{95}$ Consequently, this has aided the SAHRC in playing a leading role in the implementation of the provisions of the ICESCR in the State. ${ }^{96}$ The ICESCR was ratified by South Africa on 12

\footnotetext{
Consideration of report submitted by South Africa par 12

Consideration of report submitted by South Africa par 14 .

Acceded on 28 August 2002.

91 Consideration of reports submitted by States parties under Article 40 of the Covenant: Initial report of South Africa 7 March 2016 UN DOC NO: CCPR/C/SR.3234 par 10.

92 Chart on the status of National Institutions https://nhri.ohchr.org/EN/AboutUs/GANHRI Accreditation/Documents/Status\%20Accreditation\%20Chart.pdf par 16.

93 "HRC Concluding Observations on the Initial Report of South Africa: Information received from South Africa on follow-up to the Concluding Observations" on 12 May 2017 UN DOC NO: CCPR/C/ZFA/CO/1/Add.1.

94 Beredugo and Viljoen "Towards a Greater Role and Enhanced Effectiveness of National Human Rights Commissions in Advancing the Domestic Implementation of Socio-Economic rights Nigeria, South Africa and Uganda as Case Studies" 2015 48(3) The Comparative and International Law Journal of Southern Africa 401414.

95 S 184(3) of the Constitution of the Republic of South Africa.

96 Carver 2010 10(1) Human Rights Law Review 2. The socio-economic rights contained in the Constitution of the Federal Republic of South Africa are as follows: s 26 Right to Access to Adequate Housing; s 27 Right to Healthcare, Food, Water and Social Security; s 29 Right to a Basic Education; s 30 Language and Culture; s 31 Non-Denial of Cultural, Religious and Linguistic Communities.
} 
January $2015 .{ }^{97}$ It submitted its first report to the CESCR on 12 January $2017,{ }^{98}$ in which it informed the CESCR that the SAHRC participates actively in the implementation of the provisions of the treaty at the domestic level and it was consulted during the preparation of the report, ${ }^{99}$ as it is mandated to monitor and receive complaints of violations of the provisions of the treaty by its enabling law. ${ }^{100}$

The SAHRC on its part submitted a report to the CESCR in which it raised issues of concern and recommended areas that it observed the States party had breached in its bid to implement the provisions of the treaty, which should be included in the CESCR LOls to South Africa. ${ }^{101}$ It however corroborated the States party claim that it consulted widely in the preparation of the report to the CESCR. ${ }^{102}$ The SAHRC also, pointed out some issues which hindered the implementation of the ICESCR, which include the inclusion of a declaration by the States party at the point of ratification of the treaty that the implementation of the right to education as provided by articles 13(2)(a) and 14 of ICESCR will be progressive, subject to its National Education Policy and the availability of resources. The SAHRC viewed this declaration as a hindrance to the justiciability of the right to education in the State. ${ }^{103}$ Also, the failure of the States party to ratify the Optional Protocol to the ICESCR, is viewed by the SAHRC as a denial of the citizens right to access effective remedy for violations of their treaty rights, where they have exhausted domestic remedies. ${ }^{104}$ It also drew the attention of the CESCR about its inability to discharge its mandate effectively due to inadequate funding, despite seeking the intervention of the Parliament and several treaty bodies. ${ }^{105}$

The SAHRC also made recommendations to the CESCR which should be included in its LOls to the States party whether it intends to withdraw its Declaration to articles $13(2)(a)$ and 14 of the ICESCR. ${ }^{106}$ The Government should also furnish the Committee with its action plan on the ratification of $\mathrm{OP}$ to the ICESCR. ${ }^{107}$ Information on plans to increase funding for the SAHRC was equally suggested to be included in the LOls by the South African Government by the NHRI. ${ }^{108}$ Regarding protection of other rights in the treaty, it was recommended that regarding the right to work under article

97 "Reporting Status for South Africa" http://tbinternet.ohchr.org/_layouts/TreatyBodyExternal/ Countries.aspx?CountryCode=ZAF\&Lang=EN (accessed 2018-06-22). Initial report of States parties due in 2017 (date received: 24 April 2017) South Africa, UN DOC NO: E/C.12/ZAF/1.

99 Initial report of South Africa par 6.

100 Initial report of South Africa par 31.

101 South African Human Rights Commission "NHRI report to the United Nations Committee on Economic, Social and Cultural Rights for consideration during the $61^{\text {st }}$ pre-seasonal working group adoption of list of issues regarding the South Africa's Government initial report under the ICESCR" (August 2017) http://tbinternet.ohchr.org/Treaties/CESCR/Shared\%20 Documents/ZAF/INT CESCR IFL ZAF 28910 E.pdf (accessed 2018-05-12).

102 SAHRC report to the CESCR par 2.

103 SAHRC report to the CESCR par 4.

104 SAHRC report to the CESCR par 5.

105 SAHRC report to the CESCR par 8.

06 SAHRC report to the CESCR par 121

107 SAHRC report to the CESCR par 122.

108 SAHRC report to the CESCR par 125 
6 , that updated information on the unemployment rate should be requested by the CESCR, ${ }^{109}$ and the level of implementation of minimum wage within the territory of South Africa, should be provided. ${ }^{110}$ However, despite the issues raised by the SAHRC in its report to the CESCR, the Committee did not include most of the concerns raised by the NHRI in its LOls to South Africa $^{111}$ as only information on steps taken by the States party to curb the unemployment rate of its citizens, ${ }^{112}$ and the implementation of the national minimum wage were requested. ${ }^{113}$ The CESCR did not mention or request any information on the SAHRC nor the possible ratification of OP to the ICESCR in its LOls ${ }^{114}$ which it is submitted, gives an impression that it does not attach much importance to the contributions of NHRIs to its activities, despite issuing a general comment concerning NHRls. However, the South African initial report is due for review by the CECSR in September 2018, ${ }^{115}$ and it is an ideal opportunity for the CESCR to take up the issues raised by the SAHRC especially that of its inadequate funding and the failure of the South African Government to ratify OP to the ICESCR.

\section{Monitoring the implementation of human rights at the domestic level}

The SAHRC at the domestic level, has been overseeing the implementation of human rights by the States party, for instance, when South Africa indicated its interest to withdraw from being a party to the Rome Statute of the International Criminal Court (ICC) it added its voice to those who opposed the move by the Government. It was of the view that "The ICC is the only permanent International Criminal Court, and is a crucial instrument of international criminal justice, particularly with respect to ending impunity for perpetrators of international crimes" and that there was no alternative to the ICC, as such withdrawal from the treaty was viewed by the SAHRC as regression from the rule of law by South Africa. ${ }^{116}$ Recently, a High Court in the state ruled against the Government's bid to withdraw from the ICC. As a result, the Government withdrew its intention to withdraw from the ICC as suggested by the SAHRC and others that opposed the withdrawal. ${ }^{117}$ The SAHRC has appeared before courts of law as amicus curiae (friend of the

SAHRC report to the CESCR par 371.

10 SAHRC report to the CESCR par 432.

111 List of Issues in relation to the initial report of South Africa by the Committee on Economic, Social and Cultural Rights (November 2017) UN DOC NO: E/C. 12/ZAF/Q/1.

112 List of issues in relation to the initial report of South Africa par 10.

113 List of issues in relation to the initial report of South Africa par 13.

114 List of issues in relation to the initial report of South Africa par 1.

115 CESCR "International Covenant on Economic, Social and Cultural Rights $64^{\text {th }}$ Session" $(24$ September 2018-12 October, 2018) http://tbinternet.ohchr.org/_layouts/treatybodyexternal/ SessionDetails1.aspx?SessionID=1200\&Lang=en (accessed 2018-06-9).

116 "SA Human Rights Commission 'concerned' by ICC withdrawal" (22 October, 2016) http://citizen.co.za/1322980/sa-human-rights-commission-concerned-by-icc-withdrawal/ (accessed 2016-10-24).

117 "SA Revokes its Intent to Withdraw from the ICC" (8 March 2017) http://www.news24.com/SouthAfrica/News/sa-revokes-its-intent-to-withdraw-from-the-icc20170308 (accessed 2017-03-13). 
court), ${ }^{118}$ in the case of The Government of the Republic of South Africa $v$ Irene Groomboom. ${ }^{19}$ Not only did the SAHRC appear as an amicus, ${ }^{120}$ it undertook to monitor the implementation of the judgment, which concerned the right of citizens access to housing. ${ }^{121}$ The SAHRC has also initiated litigations in its bid to protect the human rights of individuals. For instance, it sued a newspaper columnist, alleged to have made a publication alleged to contain hate speech. ${ }^{122}$ The SAHRC has engaged in extensive public enlightenment, production of educational materials, teacher training, sponsorship of school activities and organising professional training for security enforcement officers and health workers on issues related to the protection and promotion of human rights in South Africa. ${ }^{123}$ Despite the SAHRC being a creation of the Constitution, it is observed that the President has the discretion of appointing Commissioners on the recommendation of the Parliament, who will manage the affairs of the SAHRC. These appointees of the President could be members of his political party, which could lead to the SAHRC's independence being compromised. ${ }^{124}$ Nevertheless, it is observed that the SAHRC has substantially complied with the Paris Principles, for being able to contribute to the review process of both treaty bodies and monitor the implementation of human rights at the domestic level.

\section{MOROCCO: NATIONAL HUMAN RIGHTS COUNCIL (CNDH)}

\section{The mandate of the CNDH}

Morocco ratified both the ICCPR and the ICESCR on the 3 May $1979 .{ }^{125}$ Unlike South Africa, Morocco is a state that falls under the civil law jurisdiction that applies the principle of pacta sunt servanda (agreements must be kept), meaning international treaties that it ratified or acceded to, automatically become part of its domestic legislation. Both treaties are therefore not only part of its domestic law but also above it in order of precedence. ${ }^{126}$ The CNDH, is also a Paris Principles compliant NHRI as it

118 Stevens and Ntlama 201620 Law Democracy and Development 62; for instance it appeared in the case of University of Stellenbosch Legal Aid Clinic v Minister of Justice and Correctional Services CCT $127 / 15$ as amicus curiae before the Constitutional Court, where it urged the Court to uphold the judgment of the lower court (High Court) which declared s $65 \mathrm{~J}(2)(\mathrm{b})(\mathrm{i})$ and $65 \mathrm{~J}(2)(\mathrm{b})(\mathrm{ii})$ of the Magistrates Courts Act 1944 as inconsistent with the South African Constitution and therefore invalid.

119 CCT11/00.

120 CCT11/00 par 97.

121 Ibid.

122 South African Human Rights Commission v Qwelane Case No: 44/2009 EX JHB.

123 Mubangizi 2015 48(1) Comparative and International Law Journal of Southern Africa 132.

124 Mubangizi 2015 48(1) Comparative and International Law Journal of Southern Africa 132-133.

125 "Report Status for Morocco" http://tbinternet.ohchr.org/_layouts/TreatyBodyExternal/ Countries.aspx?CountryCode=MAR\&Lang=EN (accessed 2018-06-10).

126 Harland "The Status of the International Covenant on Civil and Political Rights (ICCPR) in the Domestic Law of State Parties: An Initial Global Survey through UN Human Rights Committee Documents" 2000 22(1) Human Rights Quarterly 187235. 
has been accredited with an "A" status by the global accreditation body of NHRIs. ${ }^{127}$ As discussed earlier, these institutions are required to engage in the promotion and protection of human rights within the territory of State parties ${ }^{128}$ and they must be vested with as broad a mandate as possible. ${ }^{129}$ The CNDH was established with a mandate to investigate and monitor human rights violations throughout the territory of Morocco. ${ }^{130}$ It is also mandated to collaborate with relevant Government agencies in the implementation of the provisions of the treaties which Morocco has ratified or acceded to. ${ }^{131}$ In addition, where UN charter bodies have examined the reports submitted by the States party as the case maybe, the CNDH shall make recommendations to the relevant Government agencies on the implementation of the concluding observations issued to it, ${ }^{132}$ and also encourage the States party to submit follow-up reports to the relevant charter body on the level of implementation of the concluding observations submitted to it. ${ }^{133}$ Among the responsibilities expected to be assigned to an NHRI is that it participates in the review process of UN charter bodies. ${ }^{134}$

\section{Submission of reports to charter bodies by the CNDH}

The Moroccan NHRI has participated in the review mechanisms of both the ICCPR and CESCR by presenting separate reports before each Committee. With regards to the HRC, the Moroccan Constitution incorporated some provisions of civil and political rights as contained in the ICCPR. ${ }^{135}$ Consequently, in response to the HRC's invitation for NHRls to participate in its review process, ${ }^{136}$ the $\mathrm{CNDH}$ participated in submitting a report at the LOls stage, ${ }^{137}$ and made suggestions on issues that should be included in the LOls which the HRC was going to forward to the States party for its response. For instance, it recommended that the timeframe for Morocco's acceding to OP1 and second optional protocol (OP2) to the ICCPR should be requested, ${ }^{138}$ along with measures taken by Government to implement

\footnotetext{
Chart on the status of National Institutions.

Article 1 of the Paris Principles.

29 Article 2 of the Paris Principles.

130 Article 4 of Law No 1.11.19 of 1 March 2011 Establishing the National Human Rights Council.

131 Article 10 of the CNDH establishment law.

132 Article 13 of the CNDH establishment law.

133 Article 15 of the CNDH establishment law.

134 Article $3 e$ of the $\mathrm{CNDH}$ establishment law.

135 Dahir (Moroccan Royal Decree) No 1-11-82 (2011). Other constitutional guarantees in the 2011 Moroccan Constitution for instance are: Right to Life (art 20); Prohibition of Torture, Cruel, Inhuman or Degrading Treatment (art 22); Fair Trial Rights, with arbitrary and secret detentions prohibited and person found culpable shall be severely punished (art 23) and Freedom of Expression (art 25).

136 Paper on the working relationship between HRC and NHRls http://tbinternet.ohchr.org/ layouts/treatybodyexternal/Download.aspx?symbolno=CCPR\%2fC\%2f106\%2f3\&Lang=en par 9.

137 Contribution of the National Council of Human Rights of Kingdom of Morocco (CNDH) to the Human Rights Committee for the establishment of the list of issues (LOls) by Morocco prior to consideration of the sixth report UN DOC NO: CCPR/MAR/23037.

138 Contributions of the CNDH to the HRC on its list of issues par 84.
} 
the recommendations of the $\mathrm{CNDH}$ on breaches of human rights by its officials. ${ }^{139}$ The question of whether Morocco will amend its law to allow individuals access to their lawyers immediately when they are taken into the custody by the state was also to be raised. ${ }^{140}$ The HRC in keeping with its practice, sought information on the functions and scope of the mandate of the $\mathrm{CNDH}$, more specifically if it has the competence to receive complaints from the public. ${ }^{141}$ The $\mathrm{CNDH}$, in the report it submitted to the HRC after the States party had responded to the LOls, informed the HRC that one of its responsibilities was to receive complaints from the public, and 10,050 complaints of violations of human rights were submitted to it between January 2014 and June 2016. ${ }^{142}$ It urged the HRC to include in its concluding observations at the end of the review, that funding for the $\mathrm{CNDH}$ should be increased to enable it to carry out its functions more effectively. ${ }^{143}$ Another vital piece of information included in its report was on the status of the alleged State practice of enforced disappearances. This practice is defined as:

"Enforced disappearance is considered to be the arrest, detention, abduction or any other form of deprivation of liberty by agents of the State or by persons or groups of persons acting with the authorization, support or acquiescence of the State, followed by a refusal to acknowledge the deprivation of liberty or by concealment of the fate or whereabouts of the disappeared person, which place such a person outside the protection of the law.

Enforced disappearances are deemed to have occurred once individuals are detained by the authorities of a state and it refuses to disclose the location of the detainees, meaning they have been placed "outside the protection of the law". ${ }^{145}$ In extreme cases, these detainees are murdered and then disposed of without the knowledge of the public which is a more permanent solution for the Government, as subjects of the disappearances may never be found which means the chances of the Government being held accountable for the disappearances is low. ${ }^{146}$ The CNDH informed the HRC in its report that 385 burial sites had been discovered with certainty that they contained the victims of enforced disappearances by the State. ${ }^{14}$ The HRC commended the CNDH on its efforts in investigating the victims of enforced disappearances in its concluding observations. ${ }^{148}$ It is however

139 Contributions of the CNDH to the HRC on its list of issues par 82.

140 Contributions of the CNDH to the HRC on its list of issues par 23.

141 List of issues in relation to the $6^{\text {th }}$ periodic report of Morocco 9 May 2016 UN DOC NO: CCPR/C/MAR/Q/6 par 2.

142 Submission of the National Human Rights Council of Morocco to the Human Rights Committee on the list of issues and replies provided by the Government (2016) UN DOC NO: ICCPR/NHS/MAR/25254 par 8.

143 Submission of the CNDH to the replies of Morocco on the list of issues par 1.

144 Article 2 of the International Convention for the Protection of All Persons from Enforced Disappearance (2006)

145 Satterthwaite "Extraordinary Rendition Disappearances in the War on Terror" 200710 Gonzaga Journal of International Law 7073.

146 Payne and Abouharb "The International Covenant on Civil and Political Rights and the Strategic Shift to Forced Disappearance" 2016 15(2) Journal of Human Rights 163166.

147 Contributions of the CNDH to the HRC on its list of issues par 16.

148 Human Rights Committee: Concluding observations on the $6^{\text {th }}$ periodic report of Morocco (2016) UN DOC NO: CCPR/C/MAR/CO/6 par 27. 
submitted that the failure of the HRC to recommend the allocation of more funds to the CNDH in its concluding observations as requested by this NHRI, was a notable drawback to this particular review. As noted earlier, the HRC failed to make a recommendation to the South African authorities to increase funding to the SAHRC. Thus, there is a need for international bodies like the HRC to give more support to bodies like the $\mathrm{CNDH}$, by urging States parties to provide them with more funds to enable them to discharge their mandates effectively.

Furthermore, rights contained in the ICESCR, which include equal rights to healthcare, education and decent housing are enshrined in the Moroccan Constitution. ${ }^{149}$ Prelude to the review of the fourth periodic report of Morocco by the CESCR, the States party in its report stated that the CNDH is mandated to investigate cases which involve the violation of the provisions of the ICESCR, and provide redress in accordance with the international obligations of Morocco. ${ }^{150}$ In addition, it was also reported by the States party that the CNDH received 1289 complaints of which most relate to economic, social and cultural rights. ${ }^{15}$

In the CNDH's report to the CESCR, it asserted that it was consulted during the preparation of the fourth periodic report of Morocco. ${ }^{152}$ The CNDH also explained the issues that impede the right to education which include delayed pre-school education, chronic deficits in higher education and general lack of quality education within Morocco. ${ }^{153}$ It however stated that it is in collaboration with other national partners to curb the high rate of school dropouts within the territory of the States party. ${ }^{154}$ Regarding the right to employment, the CNDH was of the opinion that the quality of employment for persons with disability and women without a diploma limits their access to the labour market. ${ }^{155}$ The challenge foreigners face, especially migrants and asylum seekers, in securing employment was a point of concern for the $\mathrm{CNDH} .{ }^{156}$

Regarding the right to health, the CNDH informed the CESCR that it collaborated with the Ministry of Health in May 2014, and launched a National Strategy on HIV/AIDS in order to reduce the stigmatisation of those living with the disease and also to protect and promote the human rights of those with HIV/AIDS. ${ }^{157}$ In addition, access to culture, according to the $\mathrm{CNDH}$ among Moroccan people was weak, as there was the need to

49 Article 31 of the Moroccan Constitution 2011.

150 Fourth periodic reports of States parties due in 2009 (date received: 24 January 2013) Morocco, UN DOC NO: E/C.12/MAR/4 par 18.

151 List of issues relating to the fourth periodic report of Morocco: Replies of Morocco to the list of issues (date received 9 July 2015) UN DOC NO: E/C.12/MAR/Q/4/Add.1 par 4.

152 Summary of report submitted to the Committee on Economic, Social and Cultural Rights (2015) par 4.

153 Summary of report submitted to the CESCR par 9.

154 Summary of report submitted to the CESCR par 10.

155 Summary of report submitted to the CESCR par 13

156 Summary of report submitted to the CESCR par 14.

157 Summary of report submitted to the CESCR par 16. 
accelerate the adoption of laws that will strengthen the implementation of the cultural and linguistic diversity of the Moroccan people.

Despite the submission of a report by the CNDH to the review of the fourth periodic report of the States party by the CESCR, the Committee, besides commending the States party for the establishment of several institutions such as the Economic, Social and Environmental Council by Morocco in its concluding observations, did not make inquiries during the review of the States party report on the ability of the CNDH to promote and protect ICESCR rights within the territory of the States party. ${ }^{159}$ It also failed to mention the CNDH or make any recommendations with regards to strengthening its functions to enable it to discharge its mandate more effectively. ${ }^{160}$ It is submitted that unlike the HRC, the CESCR does not encourage States parties to show more commitment in allowing NHRIs to comply with the mandate provided by the Paris Principles.

\section{Domestic implementation of Treaty rights}

As pointed out earlier, the Moroccan Constitution guarantees the protection of both civil and political rights, ${ }^{161}$ and those of economic, social and cultural rights. ${ }^{162}$ Consequently, the $\mathrm{CNDH}$ is mandated to monitor the implementation of these provisions. ${ }^{163}$ However, on a positive note, it has made contributions to the Bill that seek to combat violence against women by recommending to the Parliament the incorporation of concluding observations and recommendations issued by various charter bodies which include the CESCR and that of the HRC to Morocco. ${ }^{164}$ Also, the CNDH in its effort to persuade the Moroccan Parliament to align its proposed domestic Workers Employment Bill with the relevant treaty, submitted a memorandum to the Parliament, recommending the ratification of the Domestic Workers Convention (C189), and making the proposed Bill compatible with the provisions of the treaty. ${ }^{165}$ The CNDH also, organised a national conference on the domestication of international human rights law, where domestication issues and challenges were examined by stakeholders and recommendations were made on how to harmonise domestic law with human rights treaties, which Morocco is a party to. ${ }^{166}$

158 Summary of report submitted to the CESCR par 24.

159 Summary of record of the $65^{\text {th }}$ Meeting of the CESCR where it considered the $4^{\text {th }}$ periodic report of Morocco submitted under arts 16 and 17 of ICESCR on 30 September 2015 UN DOC NO: E/C.12/2015/SR.64.

160 Concluding observations on the fourth periodic report of Morocco 8 October 2015 UN DOC NO: E/C.12/MAR/CO/4 par $4 a-c$.

161 Articles 20-25 of the Moroccan Constitution 2011.

162 Article 31 of the Moroccan Constitution 2011.

163 CNDH Establishment Law.

164 "Fight Against Violence Against Women: Opinion of the Council on Bill No: 103.13" http://www.cndh.org.ma/an/newsletter/bulletin/26737/251 (accessed 2018-06-12).

165 "Domestic Workers Conditions Employment Bill No: 12-19" http://cndh.ma/sites/default/ files/cndh_-_debat_publique_travail_domestique_uk-_.pdf (accessed 2018-06-10) 3 .

166 "National Conference in Laayoune: Domestication of International Human Rights and Humanitarian Law" (2016) http://www.cndh.org.ma/an/article/national-conference-laayounedomestication-international-human-rights-law-and-international (accessed 2018-06-10). 
However, despite its contribution to the charter bodies, and its efforts to promote human rights, the CNDH's protective mandate is not impressive as the NHRI has been described as an "empty shell", as it failed to play an active role in the protection of human rights at the domestic level. It has failed to expose human rights violations committed by security forces, it is rather swift to justify their occurrence without carrying out any investigation. ${ }^{167}$ Also, the $\mathrm{CNDH}$ has only been able to present a single annual report in 2014 since its establishment. This is also viewed as its inability to fulfil its mandate, as the report failed to outline its successes and challenges in the implementation of its mandate, as it focused solely on the "general activities of the CNDH". ${ }^{168}$ Consequently, it is submitted that the failure of the CNDH to implement its protective mandate effectively within the territory of the States party is a drawback to achieving its full potential.

5

\section{NIGERIA: NATIONAL HUMAN RIGHTS COMMISSION (NHRC)}

\section{Establishment and scope of mandate}

The National Human Rights Commission (NHRC) was established in $1995,{ }^{169}$ pursuant to the resolution of the UN General Assembly mandating all member states to establish NHRIs in their territories. The NHRC is an extra-judicial mechanism created for the promotion and protection of human rights within the domestic territory of Nigeria. ${ }^{170}$ When the NHRC was created, it was mandated to oversee matters that had to do with human rights contained in the Constitution of the Federal Republic of Nigeria, the African Charter on Human and Peoples Rights and all other international human rights treaties that Nigeria is a signatory to. ${ }^{171}$ It also has the mandate to monitor and investigate all alleged human rights violations and make recommendations to the President for their prosecution. ${ }^{172}$ It shall equally seek appropriate remedies on behalf of victims of human rights violations, $^{173}$ and carry out generally promotional activities like the organisation of local and international talk shops for public enlightenment. ${ }^{174}$

Some of the deficiencies of this Act include the vague provisions of its powers which provide that the commission shall have power to "do all things which by this Act or any other enactment are required or permitted to be done by the Commission". ${ }^{175}$ Another observation was the Attorney-General of the Federation (AGF) power to give the Governing Council of the NHRC

167 Mayrhofer "International Human Rights Protection: The Role of National Human Rights Institutions - A Case Study" (2016) www.fp7-frame.eu>frame-reps-4-3 (accessed 2018-0612) 55.

168 Mayrhofer www.fp7-frame.eu>frame-reps-4-3 49.

169 National Human Rights Commission Act (1995) now CAP N46 Laws of the Federation of Nigeria 2004 (hereinafter "National Human Rights Commission Act 1995").

170 About Us: National Human Rights Commission of Nigeria 1.

171 S 5(a) of the National Human Rights Commission Act 1995.

172 S 5(b) of the National Human Rights Commission Act 1995.

173 S 5(c) of the National Human Rights Commission Act 1995.

174 S 5(f) of the National Human Rights Commission Act 1995.

175 S 6(a) of the National Human Rights Commission Act 1995. 
"directives" over the exercise of its functions. ${ }^{176}$ These shortcomings of the NHRC are understandable, as it was established by a Military regime which is considered as the worst violator of human rights in the history of Nigeria. As such the concern raised was that it merely created the NHRC with the sole intention of diverting attention from its appalling human rights record, and to also "hoodwink the international community". ${ }^{177}$ The fact that the NHRC was not really independent, its Executive Secretary was dismissed from his post by the then Head of State in power, for criticising the violations of human rights by security officials of the Government despite protests by NGOs. ${ }^{178}$ Another Head of the NHRC was redeployed from her post for presenting an unfavourable report before the United Nations Human Rights Council at its $9^{\text {th }}$ Session in 2008, on Nigeria's human rights record. ${ }^{179}$

Recently, the NHRC Act was significantly amended, ${ }^{180}$ to strengthen the functions, powers and independence of the NHRC to enable it to discharge its functions effectively in accordance with the Paris Principles. ${ }^{181}$ Some of the major amendments include the addition of the ICCPR and ICESCR as some of the international treaties it is mandated to oversee their implementation. ${ }^{182}$ This provision is controversial, as Nigeria is a dualist state, where before a treaty becomes law, it must be incorporated by the National Assembly as section 12(1) provides thus:

"No treaty between the Federation and any other country shall have the force of law except to the extent to which any such treaty has been enacted into law by the National Assembly."

The Supreme Court of Nigeria has restated this position on Nigeria's dualist status in the case of Abacha $v$ Fawehinmi, ${ }^{184}$ when it held thus:

"An international treaty entered into by the Government of Nigeria does not become binding until enacted into law by the National Assembly. Before its enactment into law by the National Assembly it has no such force of law as to make its provision justiciable in our Courts."

Because of Nigeria's status as a dualist state, how can the NHRC promote and protect the provisions of both treaties within Nigeria without their being incorporated into the domestic legislation of the Nigerian state? Enabulele is of the view that "the National Assembly can decide to make the provision of a treaty a national policy, by reproducing the provision in an Act of the National Assembly without necessarily making the treaty the subject of the Act". In addition, both the ICCPR and ICESCR were included in the

176 S 17 of the National Human Rights Commission Act 1995.

177 Okafor and Agbakwa "On Legalism, Popular Agency and 'Voices of Suffering': The Nigerian National Human Rights Commission in Context” 2002 24(3) Human Rights Quarterly 622 665-666.

178 Durojaiye 2008 24(4) Netherlands Quarterly of Human Rights 569-570.

179 Dada "Impediments to Human Rights Protection in Nigeria" 2012 18(1) Annual Survey of International and Comparative Law 82.

180 National Human Rights Commission Act 2010 (as amended).

181 About Us: National Human Rights Commission of Nigeria 1.

182 S 5(a) of the National Human Rights Commission Act 2010.

183 Constitution of the Federal Republic of Nigeria 1999 (as amended).

184 (2000) 6 NWLR pt 660228.

185 Abacha v Fawehinmi supra 228 par F-G. 
NHRC amendment Act, $^{186}$ and can now be considered as part of the Nigerian legislation. ${ }^{187}$ Ekhator is also of the opinion that a treaty can be incorporated as part of Nigerian law by enacting it as subsidiary legislation. ${ }^{188}$ However, it is submitted that until the courts make a pronouncement on the applicability of the provisions of both treaties, or the Nigerian National Assembly formally incorporates them into the domestic legislation of the States party, its justiciability within the territory of Nigeria will continue to be uncertain.

\section{Participation in the activities of Treaty mechanisms}

Nigeria ratified the ICCPR on 29 July $1993,{ }^{189}$ and submitted its initial report to the HRC in 1996, ${ }^{190}$ which was considered the same year. ${ }^{191}$ Although the NHRC was a new creation at the time of the review, its officials were part of the Government delegation. ${ }^{192}$ The HRC commended the military Government for establishing the NHRC with the mandate to promote and protect human rights, ${ }^{193}$ and recommended that the States party mandate the NHRC to embark on public enlightenment on the rights and remedies available to individuals in the ICCPR, and those rights of the treaty that had been incorporated in the Constitution of Nigeria. ${ }^{194}$ The second periodic report of the States party was scheduled to be submitted on 28 October 1999, to the HRC for review. However, Nigeria has failed or refused to comply with the submission date. Consequently, the report has been outstanding for more than 16 years, this failure to submit a report before the HRC for review has denied the NHRC the opportunity to participate in the activities of the HRC. ${ }^{195}$

Nigeria also ratified the ICESCR on 29 July $1993,{ }^{196}$ and submitted its initial report to CESCR on 7 February 1996, however, the report did not contain information relating to the establishment of the NHRC. ${ }^{197}$ However,

186 S 5(a) of the National Human Rights Commission Act 2010.

187 Enabulele "Implementation of Treaties in Nigeria and the Status Question: Whither Nigeria?" 200917 African Journal of International and Comparative Law 326332.

188 Ekhator 'The Impact of the African Charter on Human and Peoples' Rights on Domestic Law: A Case Study of Nigeria" 2015 41(2) Commonwealth Law Bulletin 253257.

189 Reporting Status for Nigeria tbinternet.ohchr.org/_layouts/TreatyBodyExternal/Countries. aspx?CountryCode=NGA\&Lang=EN (accessed 2018-06-11).

190 Consideration of reports submitted by States parties under Article 40 of the Covenant: Initial report of Nigeria 7 February 1996 UN DOC NO: CCPR/C/92/Add.1.

191 Concluding observations of the Human Rights Committee: Nigeria, 3 April 1996 UN DOC NO: CCPR/C/79/Add.64.

192 Consideration of reports submitted by States parties under article 40 of the Covenant: Initial report of Nigeria 9 July 1996 (continued) UN DOC NO: CCPR/C/92/Add.1 par 74.

193 Consideration of reports submitted by States parties under article 40 of the Covenant: Initial report of Nigeria 7 February 1996 UN DOC NO: CCPR/C/92/Add.1 par 9.

194 Consideration of report submitted by Nigeria to the ICCPR par 39.

195 Report of the Human Rights Committee 2015/2016 17.

196 Reporting status for Nigeria tbinternet.ohchr.org/_layouts/TreatyBodyExternal/Countries. aspx?CountryCode=NGA\&Lang=EN.

197 Implementation of the International Covenant on Economic, Social and Cultural Rights: Initial report by States parties under articles 16 and 17 of the Covenant submitted by Nigeria on 7 February 1996 UN DOC NO: E/C.12/1998/SR.8 par 1-36. 
the CESCR welcomed the creation of the NHRC in its concluding observations issued to Nigeria after the review of its initial report, despite not participating in the review process. ${ }^{198}$ The second periodic report of Nigeria was due on the 1 January, 2000, which it failed to submit. ${ }^{199}$

However, Nigeria has been consistent in submitting its reports before the African Commission on Human and Peoples' Rights (African Commission), ${ }^{200}$ where the African Commission reviewed its fifth periodic report in 2014. ${ }^{201}$ Despite the preparation of its reports being more cumbersome since rights contained in the African Charter on Human and Peoples' Rights, ${ }^{202}$ composed both civil and political rights, on the one hand, and economic, social and cultural rights on the other, and the report(s) are submitted every two years. ${ }^{203}$ In addition, in the Nigerian Constitution, civil and political rights that are contained in Chapter 4 are justiciable before the Courts, while those of economic, social and cultural rights in Chapter 2 are not. ${ }^{204}$ Notwithstanding these inconsistencies of Nigeria's compliance in its reporting obligations to treaty bodies, the NHRC submitted a report before the United Nations Human Rights Council on Nigeria's human rights situation that was critical of the Government, and there was no backlash from it. This suggests that it may be able to submit an objective report to the HRC, should the States party decide to submit a report for review without any repercussions from the authorities. ${ }^{205}$ Additionally, Nigeria has failed to ratify all the Optional Protocols to both treaties, which could have given an idea of the role the NHRC could have played in their implementation, ${ }^{206}$ but the African Commission on its review of Nigeria's fifth periodic report made a recommendation that it (Nigeria) should ratify Optional Protocols to both treaties which will enable individuals within its territory to gain access to the individual complaint mechanisms. ${ }^{207}$

In Nigeria's sixth report to the African Commission ${ }^{208}$ the non-justiciability of ESC rights were reaffirmed. ${ }^{209}$ It also mentioned the NHRC, as a body

198 Consideration of reports submitted by States parties under articles 16 and 17 of the Covenant: concluding observations of the Committee on Economic, Social and Cultural Rights to Nigeria on 16 June 1998 UN DOC NO: E/C.12/i/Add.23 par 6.

199 Concluding observations of CESCR issued to Nigeria par 43.

$20038^{\text {th }}$ Activity Report on of the African Commission on Human and Peoples' Rights: Submitted in accordance with article 54 of the African Charter on Human and Peoples' Rights 2015 par 25

201 Nigeria's $5^{\text {th }}$ periodic Country report: 2011-2014 on the Implementation of the African Charter on Human and Peoples Rights in Nigeria 2014.

202 Adopted 27 June 1981 OAU Doc: CAB/LEG/67/3 rev.5,21 I.L.M 58 (1982) entered into force 21 October 1986.

203 "Submission of State reports" http://www.achpr.org/ (accessed 2017-01-25).

204 Dada 2012 18(1) Annual Survey of International and Comparative Law 72.

205 "Report on the State of Compliance with International Minimum Standards of Human Rights by Nigeria under the Universal Periodic Review" mechanism submitted by National Human Rights Commission of Nigeria 2013.

206 Reporting status for Nigeria http://tbinternet.ohchr.org/_layouts/TreatyBodyExternal/ Countries.aspx?CountryCode=NGA\&Lang=EN (accessed 2018-05-19).

207 Concluding observations and recommendations on the $5^{\text {th }}$ periodic report of the Federal Republic of Nigeria on the implementation of the African Charter on Human and Peoples Rights (2011-2014) 2015 par 59-93.

208 Nigeria's $6^{\text {th }}$ periodic country report: 2015-2016 on the implementation of the African Charter on Human and Peoples' Rights in Nigeria (August 2017). 
that has been mandated to promote and protect human rights throughout the territory of Nigeria. ${ }^{210}$ On the recommendation by the African Commission that Nigeria should ratify Optional Protocols to both treaties, it was informed that the Attorney-General of the Federation has inaugurated an InterMinisterial Working Group, to facilitate the ratifications of some treaties including the Optional Protocols to ICCPR and ICESCR. ${ }^{211}$ Furthermore, on the recommendation of the NHRC, the Nigerian Government has established a National Group on Human Rights Treaty Reporting with one of its objectives to assist the State in fulfilling its national and international human rights obligations including the submission of reports to treaty bodies (including the HRC and CESCR), and participation in the review of the reports and the implementation of concluding observations and recommendations issued by the respective bodies. ${ }^{212}$ It is submitted that if this comes to fruition, the submission of state reports by Nigeria will greatly improve, and the opportunity to assess the ability of the NHRC to participate in the reporting procedure of charter bodies will be more readily available.

\section{Implementation of human rights within the territory of the State party}

Similar to the SAHRC, the NHRC has also been conferred with broad powers to be able to execute its mandate effectively, some of which include initiating investigations and inquiries at its own instance of human rights violations, ${ }^{213}$ visitation of police cells and detention centres and making appropriate recommendations, ${ }^{214}$ award damages or compensation in relation to violations of human rights. ${ }^{215}$ The NHRC, may summon any person or authority in pursuance of a public inquiry in relation to human rights violations, ${ }^{216}$ issue a warrant to compel a person to appear before it. ${ }^{217}$ The Act restates the independence of the NHRC when carrying out its functions, as it is not subject to the control of any authority or person. ${ }^{218}$ The NHRC shall be funded directly from the Consolidated Revenue Fund of the Federation to make it financially independent of any arm of Government. ${ }^{219}$ Awards and compensations made by the NHRC shall be binding and liable to be enforced by the Nigerian High Courts. ${ }^{220}$ Section 17 of the old Act that empowered the AGF to give directives was substituted with another one that mandates the NHRC to submit to the President and the National Assembly

209 Nigeria's $6^{\text {th }}$ periodic report 65.

210 Nigeria's $6^{\text {th }}$ periodic report 23.

211 Nigeria's $6^{\text {th }}$ periodic report 12 .

212 Nigeria's $6^{\text {th }}$ periodic report 23.

213 S 6(1)(a) of the National Human Rights Commission Act 2010.

214 S 6(1)(d) of the National Human Rights Commission Act 2010.

215 S 6(1)(e) of the National Human Rights Commission Act 2010.

${ }^{216}$ S 6(2)(b) of the National Human Rights Commission Act 2010.

217 S 6(2)(c) of the National Human Rights Commission Act 2010.

218 S 6(3) of the National Human Rights Commission Act 2010.

219 S 12(2) of the National Human Rights Commission Act 2010.

$220 \mathrm{~S} 22$ of the National Human Rights Commission Act 2010. 
an annual report of its activities, and a report of its audited accounts. ${ }^{221}$ The $\mathrm{NHRC}$ is mandated at its own instance or at the request of the Federal, State or Local Governments, to make representations on measures to be taken, in the implementation of human rights, and furthermore, can make recommendations to the AGF for the prosecution of human rights violations. $^{222}$

The NHRC has been effective in carrying out its mandate, for instance, a bloody clash occurred between the Nigerian Army and a Shiite Muslim sect, which led to the loss of many lives. ${ }^{223}$ The NHRC received many petitions, including from the Nigerian Army to investigate the circumstances that led to the clash subsequent to these requests, it set up a Special Investigation Panel to probe the dispute. ${ }^{224}$ After the investigations, the NHRC criticised the Army for its use of excessive force that led to the death of about 380 members of the Shiites Sect. It also recommended the payment of compensation to the families of those that had lost their lives. Equally, those in detention should either be arraigned before appropriate courts for trial or be released; soldiers that are found to have committed extra-judicial killings should be prosecuted. ${ }^{225}$ Another instance where it intervened on behalf of individuals whose human rights were violated was when a team of operatives from various security agencies in Abuja, the capital city of Nigeria, stormed an uncompleted building, and in the process killed seven people and injured many more. The security team alleged that the occupants of the building were members of the insurgent group Boko Haram, while the survivors of the onslaught argued that they were homeless artisans, squatting in the uncompleted building that was overrun by security operatives, the NHRC stepped in to investigate the matter. ${ }^{226}$ After completion of the investigation, the NHRC criticised the security forces for using excessive force during the raid, which resulted in deaths and injuries to the dwellers of the uncompleted building, consequently, it awarded generous compensations in favour of the victims, against the security agencies. $^{227}$ The State Security Service filed an application before a Federal High Court in an attempt to block the implementation of the decision, however, the application was refused by the Court. ${ }^{228}$ In exercising its quasijudicial mechanism, the NHRC continued to gain wide acceptance throughout the State, as more people sought its assistance in seeking

S 17 of the National Human Rights Commission Act 2010.

222 S 5(o) and (p) of the National Human Rights Commission Act 2010.

223 "Army/ Shiites Clash: NHRC Sets up Probe Panel" http://www.vanguardngr.com/2015/12/ armyshiite-clash-nhrc-sets-up-probe-panel/ (accessed 2017-11-21).

224 "Army/ Shiites Clash: NHRC Sets up Probe Panel" http://www.vanguardngr.com/2015/12/ armyshiite-clash-nhrc-sets-up-probe-panel/.

225 "Nigeria's Rights Commission Indicts Army for Killing 380 Shiites" http://www.africareview. com/news/Nigeria-Rights-Commission-indicts-army-for-killing-380-Shiites/979180-3390832format-xhtml-86n3w2/index.html (accessed 2016-11-23).

226 "Nigeria: Human Rights Commission to Investigate Apo 7 Killings" http://newsrescue.com/ nigeria-human-rights-commission-to-investigate-apo-7-abuja-killing/\#axzz4bgEtOKZv (accessed 2015-12-25).

227 "Excerpts of National Human Rights Commission Report on Apo Killings Last Year par 10.01(f).

228 "Nigeria: Court Okays NHRC's Decision in Apo Killings" http://allafrica.com/stories/ 201511302219.html (accessed 2016-11-25). 
remedies for the violations of their human rights. Between January and November 2016, it received an impressive 1,179,510 complaints from individuals throughout the Federation. This attests to the level of confidence the NHRC inspires among individuals whose rights have been violated. ${ }^{229}$

However, despite the mandate of the NHRC to protect human rights, the non-justiciability of ESC rights under the Nigerian legislation, has made it incapable of promoting their implementation, although they are viewed as having far-reaching positive implications for the poor impoverished people of Africa generally. ${ }^{230}$ Furthermore, the failure of states like Nigeria to recognise the importance of ICESCR on the same level as with the provisions of the ICCPR inhibits its effective implementation. ${ }^{231}$ This has spurred Gomez to canvass for states to create separate NHRIs that will have the mandate to promote and protect ESC rights only. ${ }^{232}$ It is however submitted that the Nigerian Constitution needs to be amended, with ESC rights made justiciable, to enable the NHRC to push for their effective implementation by the Nigerian Government.

\section{CONCLUSION}

The inability of treaty bodies to monitor the domestic implementation of treaty rights, which gave States parties the opportunity to present reports that are not in tune with realities within their territories, has spurred them into inviting NHRls to serve as a bridge in the implementation of these treaties. To discourage states from establishing "dummy" NHRIs, the Paris Principles was adopted, which specify the mandate that each state should vest its $\mathrm{NHRI}$ for it to be able to discharge its obligations. Consequently, both the HRC and the CESCR requested NHRIs that have been accredited by GANHRI with an "A" status, which implies that they are Paris Principles compliant. Of relevance, all three of the NHRIs considered in the article have an "A" status, however both the SAHRC and CNDH have submitted reports before both the HRC and CESCR, as provisions of both treaties are justiciable within their territories. The SAHRC has a broad mandate, and submitted objective reports highlighting the successes and failures of the States party in implementing the provisions of both treaties. The HRC, which has shown keen interest by making inquiries and encouraging States parties to strengthened NHRIs during the review of States parties report was impressed with the report of the SAHRC, and even commended it, and did not raise any concern regarding its mandate in its concluding observations. The CESCR, on its part did not make any inquiry regarding the status of the SAHRC in its LOls to the States party, despite receiving a comprehensive

229 "Nigeria Human Rights Commission Receives 1.7 Million Complaints: Resolves only 200" https://africajournalismtheworld.com/tag/nigeria-national-human-rights-commission-nhrc/ (accessed 2016-12-23)

230 Ibe "Implementing Economic, Social and Cultural Rights in Nigeria: Challenges and Opportunities" 201010 African Human Rights Journal 197198.

231 Kumar "National Human Rights Institutions and Economic, Social and Cultural Rights: Towards the Institutionalisation and Developmentalisation of Human Rights" 200628 Human Rights Quarterly 755763.

232 Gomez "Social Economic Rights and Human Rights Commissions" 1995 17(1) Human Rights Quarterly 155163. 
report from it. It is hoped that it will request for more information on the status of the NHRI, especially since it had raised the issue of being inadequately funded by the States party. However, since the review is still pending, the CESCR may yet take up the issue of the CNDH during the review. At the domestic level, the contributions of the SAHRC are commendable, as it engages the States party with regards to the implementation of the provisions of both treaties. It also institutes actions and appears as amicus curiae (friend of the court) before South African Courts in its bid to fulfil its obligations.

The CNDH has also submitted reports before the two committees, while the HRC in keeping with its practice made inquiries on the status of the $\mathrm{CNDH}$, both in its LOls and during the review of the States party report. While the HRC commended the CNDH for its contribution to the success of the review, it however failed to make a recommendation to the States party to provide additional funds to the $\mathrm{CNDH}$, despite the request by the NHRI for it to do so in its report. This could discourage NHRIs from participating in the activities of treaty bodies, as obliging their request to intercede on their behalf will encourage them to discharge their mandates. The CESCR on its part, after receiving the report of the $\mathrm{CNDH}$, failed to make any inquiries on the status of the CNDH in its LOls, this is another obvious setback. The CNDH has been impressive with regards to submitting reports before the treaty bodies, it is however viewed as a "lame duck" institution, with regards to overseeing the implementation of the provisions of the treaties within the domestic territories of States parties even though it has organised a conference on the domestication of treaties and made contributions to the preparation of some Bills in Parliament. It has failed to participate in the protection of the human rights of individuals, for example, its support of Government agents in cases of violations of individual human rights without investigation is seen as a failure to discharge its obligations.

Indeed, the NHRC was a creation of the Nigerian Military, and was at its infancy when Nigeria presented its report before the two committees in the 1990s. Nigeria has failed to submit a follow-up report since then. Thus, the opportunity to assess its ability whether it can present an objective report has not presented itself. Recently, Nigeria informed the African Commission that on the advice of the NHRC, a committee known as the National Group on Human Rights Treaty Reporting has been established with one of its objectives to enable Nigeria to meet its reporting obligations before treaty bodies. At the domestic level, some provisions of the ICCPR have been incorporated in the Nigerian Constitution and are therefore justiciable, the provisions of the ICESCR are not justiciable in Nigeria. A few years back, in a bid to strengthen the NHRC, both treaties were included in the Act that established the body as some of the treaties it will monitor their implementation despite Nigeria being a dualist state. While there is an ongoing debate about their application, it is submitted that it is only the incorporation of the treaties into the Nigerian legislation or the pronouncement of the courts that will cure the uncertainty. However, the NHRC has been active in the overseeing of the provisions of the ICCPR, which some of its provisions are part of the Constitution. 
The potential of NHRIs in being a bridge that fills the gap in the implementation of the provisions of human rights treaties is huge, while the HRC is making an impressive effort to convince States parties to strengthen their functions. The CESCR is not so forthcoming, as it does not reciprocate the efforts of the NHRIs. Both SAHRC and CNDH have also been urging the two committees to recommend more funding for the two NHRIs, to enable them to carry out their mandate more effectively, which they failed to do in the last round of the States parties review. This is a setback for the review process and the NHRIs. Consequently, there is a need for the committees to reciprocate the efforts of the NHRIs by adding more pressure to the States parties, to strengthen their NHRIs in accordance with the Paris Principles which will enable NHRIs to meet both their national and international obligations. 